\title{
IMPLEMENTASI KURIKULUM 2013 DENGAN PENDEKATAN SAINTIFIK (SCIENTIFIC APPROACH) PADA MATA PELAJARAN BIOLOGI
}

\author{
Miska Khairani Siregar ${ }^{1 *}$, Amrizal $^{2}$ \\ ${ }^{1,2}$ Program Studi Pendidikan Biologi, FMIPA, Universitas Negeri Medan, Jl. Willem Iskandar Psr.V, Medan \\ Estate, Medan, Indonesia, 20221 \\ *Email: khairanimiska@gmail.com
}

\begin{abstract}
Abstrak
Penelitian ini bertujuan untuk mengetahui implementasi kurikulum 2013 berbasis scientific approach pada pembelajaran biologi, penelitian ini juga bertujuan untuk memperoleh data hasil ketercapaian kurikulum 2013 dalam aspek perencaan pembelajaran, pelaksanaan pembelajaran, dan penilaian pembelajaran. Desain penelitian yang digunakan yaitu deskriptif dengan menggunakan metode observasi check list dan dilakukan dalam 3 kali pertemuan. Sampel yang diambil berjumlah 2 orang guru biologi kelas $x$ yang menerapkan kurikulum 2013. Teknik pengumpulan data dengan menggunakan lembar observasi dan pedoman wawancara, dimana untuk perencanaan sebanyak 30 butir pernyataan, pelaksaan pembelajaran sebanyak 38 butir dan 12 butir untuk penilaian pembelajaran. Hasil analisis menunjukkan bahwa rata-rata perencaan pembelajaran adalah sebesar $85,00 \%$ dengan interpretasi terlaksana baik, pelaksanaan pembelajaran yaitu $79,30 \%$ dengan interpretasi cukup baik dan penilaian pembelajaran yaitu $79,16 \%$ dengan interpretasi cukup baik. Berdasarkan hasil penelitian, implementasi kurikulum 2013 dengan pendekatan saintifik pada pembelajaran biologi di SMA Negeri 3 Binjai belum maksimal dan butuh perbaikan.
\end{abstract}

Kata Kunci : Kurikulum 2013, Pendekatan Saintifik, Pelaksanaan, Penilaian, Perencanaan

\begin{abstract}
The aims of this research is to determine the implementation 2013 curriculum based scientific approach on biology, to obtain data on the results of the 2013 curriculum achievement in learning planning aspects, implementation of learning and learning assessment. This research design using descriptive research with check list observation method and is conducted in 3 meetings. The Sample of research is 2 biology teachers in class $x$ who applied 2013 curriculum. Data collection with observation sheets and interview guidelines which as where for as many as 30 questions for learning planning, 38 questions for implementation of learning, and 12 questions for learning assessment. Results was indicated the average of learning planning was $85.00 \%$ cathegorized as done, implementation of learning was $79.30 \%$ cathegorized as enough, and learning assessment was $79.16 \%$ cathegorized as enough. Based on the results, implementation 2013 curriculum based scientific approach in SMA Negeri 3 Binjai is had not maximal get and need to be replaced.
\end{abstract}

Keywords: Implementation, Planning, Scientific Approach, 2013 Curriculum

\section{PENDAHULUAN}

Pemerintah terus berupaya meningkatkan kualitas pendidikan. Salah satu upaya tersebut adalah melalui perubahan dan pengembangan kurikulum. Perubahan dan pengembangan kurikulum perlu dilakukan karena kurikulum memiliki sifat yang dinamis agar mampu menjawab perkembangan dan tantangan zaman. Kurikulum mengarahkan segala bentuk aktivitas pendidikan untuk tercapainya tujuan pendidikan. Bentuk aktivitas pendidikan tersebut dilakukan melalui suatu proses pembelajaran sehingga siswa diarahkan untuk mencapai tujuan dan dikembangkan segenap potensinya (Kwartolo, 2007). Oleh karena itu, kurikulum memiliki peran penting sebagai pedoman bagi guru dalam menyelenggarakan kegiatan belajar mengajar.

Ditetapkannya kurikulum 2013 merupakan suatu upaya nyata pemerintah dalam mendukung para pelajar agar memiliki SDM yang berkualitas yang mampu menerobos 
perkembangan jaman. Kurikulum ini diperbuat untuk memeperbaharui kurikulum KTSP (Kurikulum Tingkat Satuan Pendidikan). Kurikulum ini dibangun berdasarkan budaya dan karakter bangsa Indonesia dimana proses pembelajaran untuk semua jenjang mulai dari tingkat sekolah dasar, sekolah menengah pertama hingga sekolah menengah atas. Kurikulum 2013 menekankan pada peningkatan dan keseimbangan softskill dan hardskill yang meliputi aspek kompetensi sikap, pengetahuan dan keterampilan. Kementerian Pendidikan dan Kebudayaan (Kemendikbud) mengamanatkan untuk mendorong peserta didik agar mampu lebih baik dalam melakukan observasi, bertanya, menalar, dan mengkomunikasikan terhadap apa yang mereka peroleh atau terima setelah menerima materi pembelajaran. (Kemendikbud, 2013).

Kurikulum 2013 sebagai Kurikulum yang kini diterapkan dibeberapa sekolah untuk kemudian dijadikan sebagai acuan evaluasi ketetapan Kurikulum di Indonesia, kedepannya tentu perlu dikaji lebih mendalam agar seluruh elemen yang terlibat di dalam pengembangannya dapat lebih maksimal dan lebih baik dalam melaksanakan tugas dan fungsi Kurikulum 2013 secara utuh dan menyeluruh. Standar proses sebagai salah satu bagian dari pengembangan kurikulum menjadi acuan utama di dalam pelaksanaan pembelajaran yang diterapkan di sekolah berdasarkan Permendikbud RI nomor 22 tahun 2016 tentang standar proses untuk satuan pendidikan dasar dan menengah yang diterapkan dalam pembelajaran ditentukan berdasarkan Kurikulum yang digunakan disetiap sekolah.

Kurikulum 2013 memiliki ciri khas, antara lain kegiatan pembelajaran menggunakan pendekatan saintifik; pembentukan sikap, pengetahuan, dan keterampilan secara terpadu; dan penanaman pendidikan karakter yang merupakan bagian dari standar proses. Kurikulum 2013 yang memiliki ciri khas tersebut belum dianalisis bagaimana implementasinya di sekolah yang menjadi piloting kurikulum 2013. Menurut Mulyasa 2013, salah satu kunci sukses dan berhasilnya kurikulum 2013 ditentukan oleh kreativitas guru dalam mengimplementasikannya.
Dalam pendekatan saintifik masalah yang diberikan guru selalu berdasarkan dengan fenomena yang selama ini terjadi di kehidupan para siswa, lalu siswa mencoba mencari jawaban dari masalah yang diberikan secara mandiri sehingga siswa tidak hanya mengetahui fakta atau prinsip, tetapi harus terampil menerapkan pengetahuannya dalam kehidupan. Penggunaan pendekaan saintifik dimaksudkan agar proses pembelajaran menjadi lebih baik. Namun, jika pendekatan saintifik digunakan semata-mata karena tuntutan Kurikulum 2013, maka akan kehilangan esensi pendekatan saintifik dan dalam praktiknya guru sulit untuk menerapkan dalam pembelajaran di kelas (Budiyanto at al, 2016).

Studi pendahuluan yang dilakukan di SMA Negeri 3 Binjai bahwa dalam pelaksanaan pembelajaran menerapkan 2 macam Kurikulum, yaitu Kurikulum 2013 pada kelas X dan IX, dan Kurikulum Tingkat Satuan pendidikan (KTSP) pada kelas XII. Hasil wawancara dengan guru bidang studi biologi kelas $X$ dan kelas $X I$ terkait dengan proses pembelajaran, bahwa guru bidang studi biologi telah menerapkan pendekatan saintifik (scientific approach) dalam pembelajaran melalui tahap mengamati, menanya, mengumpulkan informasi, mengasosiasi, mengomunikasikan. RPP yang digunakan dalam proses belajar mengajar merupakan RPP yang dibuat secara bersama-sama dengan guru biologi yang ada disekolah lain dan membentuk organisasi yaitu MGMP yang menyusun tentang RPP dan mendapat pelatihan dari pemerintah tentang kurikulum 2013.

Pelaksanaan pembelajaran merupakan tahapan mengimplementasikan RPP di dalam kelas. Dari pendapat guru bidang studi biologi kelas $\mathrm{X}$ tahapan mengimplementasikan RPP di dalam kelas tidak dapat sepenuhya terlaksana, ada beberapa kegiatan saintifik yang tidak tercapai atau tidak terlaksana, seperti tahapan mencoba/eksperimen disebabkan karena guru kesulitan dalam mengatur waktu mengajar dan pada pelaksanaan praktikum di laboratorium Biologi siswa belum dilibatkan sepenuhnya dikarenakan fasilitas praktikum yang belum memadai. 
Mengacu pada uraian tersebut, untuk kepentingan proses pembelajaran di SMA Negeri 3 Binjai, perlu dilakukan penelitian terhadap Implementasi Kurikulum 2013 dengan Pendekatan Saintifik (Scientific Approach) pada Mata Pelajaran Biologi di SMA Negeri 3 Binjai.

\section{METODE PENELITIAN}

Penelitian ini dilaksanakan di SMA Negeri 3 Binjai yang bertempat di Jalan Padangsidimpuan Nomor 10, Kecamatan Binjai Kota. Waktu penelitian dimulai pada bulan Juli - September 2018. Jenis Penelitian ini merupakan penelitian Kuantitatif dengan jenis penelitian deskriptif. Metode yang digunakan dalam penelitian ini adalah survei yaitu mengumpulkan data sebanyakbanyaknya yang mendeskripsikan/ menggambarkan suatu gejala. Populasi dalam penelitian ini adalah seluruh guru biologi yang mengajar di SMA Negeri 3 Binjai. Sampel yang diambil dari populasi sebanyak 2 orang guru biologi dengan menggunakan teknik Purposive Sample.

Teknik pengumpulan Data yang digunakan yaitu observasi, wawancara dan juga dikumentasi. Analisis data digunakan dalam penelitian ini dengan menggunakan metode deskriptif-kuantitatif. Secara deskriptif dimaksudkan yaitu mengumpulkan data sebanyak- banyaknya yang mendeskripsikan/menggambarkan suatu gejala, pristiwa berdasarkan fakta nyata dari populasi penelitian berdasarkan sampel yang menjadi perhatian dalam penelitian ini.

\section{HASIL DAN PEMBAHASAN}

Hasil dari penelitian ini didapat dari 2 orang guru biologi yang ada di SMA Negeri 3 Binjai, yang hasilnya dideskripsikan sebagai berikut.

\section{Hasil Perencanaan Pembelajaran dengan Pendekatan Saintifik}

Berdasarkan hasil analisis data (Tabel 1) yang hasilnya dirata-ratakan dari kedua guru tersebut dalam aspek perencanaan pembelajaran Maka dapat dikatakakan bahwa ketercapaian perencanaan pembelajaran sudah baik. Hal ini juga didukung dengan pernyataan guru dalam wawancara yang dinyatakan bahwa, guru-guru di SMA Negeri 3 Binjai mendapatkan pelatihan tentang kurikulum 2013 yang termasuk dalam pembuatan rencana pelaksanaan pembelajaran (RPP). Namun perencanaan pembelajaran dibuat secara berkelompok atau bersama dengan seluruh guru biologi di SMA Negeri 3 binjai dengan sekolah lain, hal ini dikarenakan di daerah tersebut membentuk organisasi MGMP( Musyawarah Guru Mata Pelajaran ) yang menyusun tentang RPP.

Tabel. 1 Hasil Perencanaan Pembelajaran Guru

\begin{tabular}{clcc}
\hline No & \multicolumn{1}{c}{ Indikator } & Nilai & Interpretasi \\
\hline 1 & Identitas Mata Pelajaran & 100 & Sangat baik \\
2 & KI Dan KD & 88,88 & Baik \\
3 & Perumusan Indikator & 88,88 & Baik \\
4 & Perumusan Tujuan Pembelajaran & 88,88 & Baik \\
5 & Pemilihan Materi Ajar & 100 & Sangat baik \\
6 & Pemilihan Sumber Belajar & 100 & Sangat baik \\
7 & Pemilihan Media Belajar & 88,88 & Baik \\
8 & Model Pembelajaran & 83,33 & Baik \\
9 & Skenario Pembelajaran & 88,88 & Baik \\
10 & Rancangan Penilaian Pembelajaran & 88,88 & Baik \\
\hline \multicolumn{2}{c}{ Nilai keseluruhan } & 85,00 & Baik
\end{tabular}

\section{Pelaksanaan Pembelajaran Menggunakan Pendekatan Saintifik}

Tabel 2 dapat diketahui berdasarkan hasil analisis data yang dirata-ratakan bahwa penilaian pelaksanaan pembelajaran yang terdapat di SMA Negeri 3 Binjai dikategorikan cukup baik yakni 
dengan nilai $79,30 \%$. Hal ini dapat dilihat juga dari hasil wawancara dengan ibu Veriati Siregar S.Pd yang menyatakan bahwa dalam pelaksanaan pembelajaran sering sekali Rencana Pelaksanaan Pembelajaran (RPP) tidak berjalan linier atau sesuai, hail ini dikarenakan adanya kendala seperti minimnya media pembelajaran, dan pada saat siswa dibuat secara berkelompok kelas menjadi tidak kondusif dikarenakan minat belajar siswa yang masih kurang padahal dalam kurikulum 2013 siswa diharapkan mampu mencari sendiri informasi maupun dapat bekerja secara berkelompok atau team work.Sedangkan pendekatan saintifik tidak dijalankan secara berurutan namun dissuaikan dengan alur pembelajaran.

Tabel 2. Data Penilaian Pelaksanaan Pembelajaran

\begin{tabular}{clcc}
\hline No & Nama guru & Nilai & Kategori \\
\hline $\mathbf{1}$ & V. Siregar & 79,82 & Cukup Baik \\
$\mathbf{2}$ & L. Manullang & 78,81 & Cukup Baik \\
\hline & Rata-rata & 79,30 & Cukup Baik \\
\hline
\end{tabular}

\section{Hasil Penilaian Pembelajaran Menggunakan Pendekatan Saintifik}

Berdasarkan hasil analisis data besarnya hasil rata-rata dari aspek penilaian pembelajaran yang dikategorikan.Maka dapat dikatakakan bahwa ketercaeriatipaian penilaian pembelajaran masih cukup baik. Sama halnya dengan hasil wawancara dengan guru yang mengajar biologi di SMA Negeri 3 binjai bahwa instrument penilaian yang terlampir di RPP dibuat secara berkelompok atau dapat dikatakan bahwa RPP bukan disusun sendiri, dan pedoman penskoran yang tertera dilampiran penilaian tidak dilakukan sepenuhnya.

Tabel 3. Data Penilaian Pembelajaran Biologi

\begin{tabular}{clcc}
\hline No & Nama Guru & Nilai & Kategori \\
\hline 1 & V. Siregar & 75,00 & Cukup \\
2 & L. Manullang & 83,33 & Baik \\
\hline & Rata-rata & 79,16 & cukup \\
\hline
\end{tabular}

\section{Hasil Analisis Implementasi Dengan Pendekatan} Saintifik

Hasil analisis penelitian implementasi kurikulum 2013 pada pembelajaran biologi dengan pendekatan saintifik di SMANegeri 3 Binjai yang dilihat secara keseluruhan baik dari perencanaan pembelajaran, pelaksanan pembelajaran dan penilaian pembelajaran. Berikut ini adalah tabel hasil analisis implementasi kurikulum 2013 dengan pendekatan saintifik.

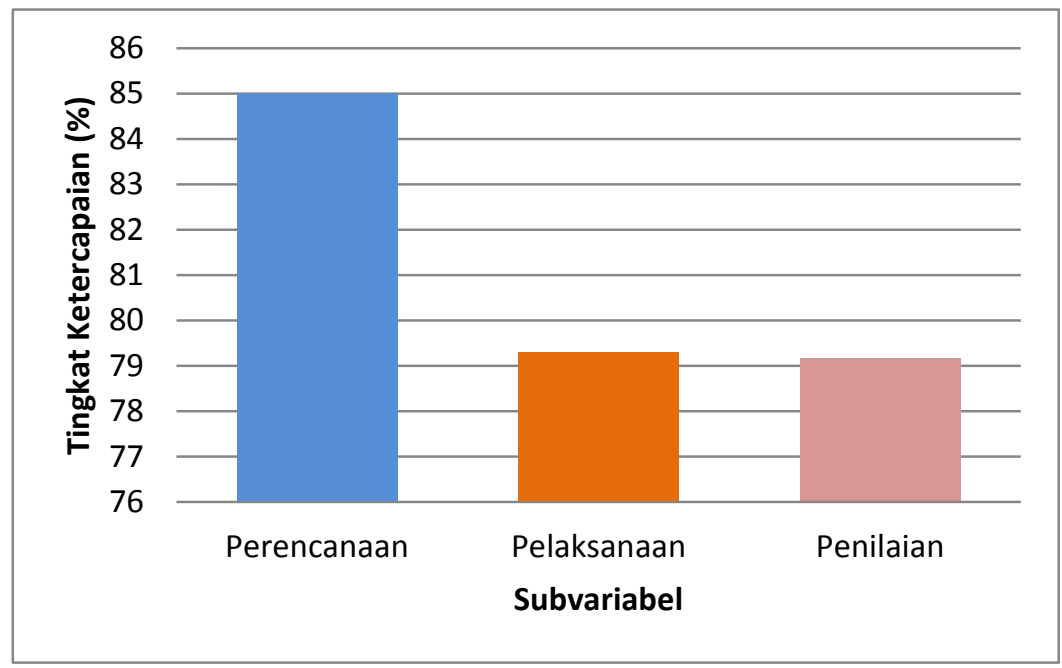

Gambar. 1 Analisis Implementasi Kurikulum 2013 dengan pendekatan saintifik di SMA Negeri 3 binjai 


\section{Perencanaan Pembelajaran}

Berdasarkan hasil observasi dan wawancara terhadap guru biologi kelas $\mathrm{X}$ menyatakan bahwa telah melakukan persiapan pembelajaran seperti menyusun RPP dan melaksanakan pendekatan saintifik. Dalam pelaksanaan pembelajaran terdapat beberapa tahapan belajar yang kurang terlaksana seperti yang tercantum pada RPP.Namun menurutnya pendekatan saintifik tidak sulit diterapkan karena guru biologi di SMA Negeri 3 Binjai telah mendapatkan panduan pelaksanaan kegiatanpembelajaran pendekatan saintifik dalam Musyawarah Guru Mata Pelajaran (MGMP) dalam implementasi Kurikulum 2013.

Menurut permendikbud No 81 A tahun 2013 tentang implementasi kurikulum menjelaskan bahwa pengembangan RPP dapat dilakukan oleh guru secara mandiri atau dapat juga dilakukan secara bersama-sama melalui MGMP didalam suatu sekolah tertentu difasilitasi dan disupervisi kepala sekolah atau guru senior yang ditunjuk oleh kepala sekolah. Penyusunan RPP yang dilakukan secara musyawarah melalui MGMP di sekolah membuat guru saling bertukar pikiran sehingga guru yang belum mengikuti pelatihan kurikulum 2013 memperoleh informasi dari guru yang telah mengikuti pelatihan

Salah satu komponen yang ada dalam pelaksanaan pembelajaran yaitu RPP, perencanaan atau persiapan yang dilakukan seorang guru sebelum mengajar secara umum adalah menyususn rencana pembelajaran dilakukan dengan cara membuat silabus dan mengembangkannya serta merancang pelaksanaannya atau membuat RPP. Dalam hal ini tentukan membutukan pengetahuan dan pemahaman yang cukup, sehingga dalam penelitian Suharno (2014) menyatakan sangat dibutuhkannya kesiapan pemerintah dalam hal ini dinas pendidikan dalam mensosialisasikan adanya kurikulum baru agar guru memiliki pengetahuan dan pemahaman dalam menyiapkan perangkap pembelajaran

$$
\text { Menurut Mulyasa (2007) dalam }
$$
mengembangkan penyusunan pembelajaran, terlebih dahulu harus diketahui arti dan tujuannya, serta menguasai secara teoritis dan praktis unsur- unsur yang terdapat pembelajarannya.Kemampuan membuat rencana pembelajaran merupakan langkah awal yang harus dimiliki oleh guru, dan sebagai muara dari segala pengetahuan teori.Langkah dasar dan pemahaman yang mendalam tentang objek belajar dan situasi pembelajaran.

\section{Pelaksaaan Pembelajaran}

Menurut hasil penilitian pelaksaan pembelajaran yang diperoleh melalui observasi dan wawancara menunjukkan bahwa secara keseluruhan ketercapaian pelaksaan pembelajara biologi di SMA Negeri 3 Binjai masih terbilang cukup baik. Data tersebut dapat dilihat dari tingkat ketercapaian indikator pada instrument observasi dan didukung hasil wawancara yang terdiri daritiga tahapan prosedur dalam pembelajaran yaitu kegiatan pendahuluan, kegiatan inti, dan kegiatan penutup. Yang masing-masing asfek terdiri dari sub aspek yang disesuaikan dengan permendikbud No. 22 tahun 2016 tentang standart proses pelaksaan pembelajaran.

Pendekatan saintifik merupakan pendekatan yang digunakan dalam pembelajaran tersebut dilakukan melalui proses ilmiah yaitu mengamati, menanya, mengumpulkan, mengasosiasi, dan mengkomunikasikan. Pembelajaran ini merupakan pembelajaran yang berpusat kepada peserta didik sedangkan guru hanya sebagai fasilitator. Kegiatan pembelajaran yang seperti ini dapat membentuk sikap, keterampilan dan juga pengetahuan peserta didik secara maksimal (Rahmatika, 2017)

Kegiatan pendahuluan merupakan pembelajaran yang berfungsi untuk menciptakan awal pembelajaran yang efektif yang memungkinkan siswa dapat mengikuti proses pembelajaran dengan baik. Kegiatan yang cenderung dilaksanakan guru yaitu menyiapkan fisik dan psikis siswa untuk mrngikuti pelajaran, mengaitkan materi dengan materi pembelajaran sebelumnya agar siswa lebih siap dalam belajar, tetapi pada pertemuan pertama tidak dilakukan, karena pada pertemuan itulah dimulai pembelajaran biologi SMA bagi anak kelas $\mathrm{X}$, 
kemudian guru memberikan informasi mengenai pembelajaran yang akan diaksanakan, dan memberikan apersepsi untuk menumbuhkan rasa keingintahuan siswa.Namun berdasarkan pengamatan dalam kegiatan pendahuluan guru sering kali melewatkan apersepsi dan motivasipadahal dalam kegiatan awal

Sanjaya, (2009) embuka pelajaran adalah suatu usaha yang dilakukan guru dalam kegiatan pembelajaran untuk menciptakan prakondisi bagi siswa agar mental maupun perhatian terpusat pada hal-hal yang akan dipelajari sehingga akan mudah mencapai kompetensi yang diharapkan. Adapun kegiatan yang kurang terlaksana yaitu kegiatan mendemonstrasikan, kegiatan menyampaikan manfaat materi pembelajaran, dan guru tidak selalu menyampaikan kemampuan yang akan dicapai siswa.

Kegiatan inti dalam pembelajaran sangat memegang peranan penting untuk mencapai tujuan pembelajaran maupun dalam membentuk kemampuan peserta didik yang telah ditetapkan.Dalam kegiatan inti pelaksanaan pembelajaran, guru menerapkan pendekatan saintifik yaitu mengamati, menanya, mengumpulkan, mengasosiasikan, dan mengkomunikasikan.

Salah Satu Cara untuk menciptakan pembelajaran yang bermakana adalah menerapkan pendekatan saintifik. Dalam kegiatan penerapan saintifik, langkah-langkah yang dilakukan oleh guru di SMA Negeri 3 Binjai disajikan sebagai berikut:

Mengamati (observasi), metode mengamati mngutamakan kebermaknaan proses pembalajaran metode ini memiliki keunggula berupa menyajikan media objek secara nyata.metode mengamati bermanfaat bagi pemenuhan rasa ingin tahu peserta didik. Sehingga proses pembelajaran memiliki kebermaknaan yang tinggi. Kegiatan mengamati hendakalah guru membuka secara luas dan bervariasi kesempatan peserta didik untuk melakukan pengamatan melalui kegiatan: melihat, menyimak, mendengar, dan membaca. Guru memfasilitasi peserta didik untuk melakukan pengamatan melatih mereka untuk memperhatikan(melihat, membaca, mendengar) hal yang penting dari suatu benda dan objek. Pada kegiatan mengamati yang dilakukan oleh guru meliputi guru memberikan waktu terhadap siswa untuk mengamati gambar, peta konsep atau membaca materi yang akan dipelajari dari sumber belajar siswa (buku paket).

Menanya, guru membuka kesempatan secara luas kepada peserta didik untuk bertanya mengenai apa yang sudah disimak, membaca, atau dilihat pada konsep pertumbuhan. Guru perlu membimbing peserta didik untuk dapat mengajukan pertanyaan. Melalui kegiatan bertanya dikembangkan peserta didik.Semakin terlatih untuk bertanya maka rasa ingin tahu peserta didik semakin banyak.Pertanyaan tersebut mejadi dasar untuk mencari informasi dari berbagai sumber yang ditentukan oleh guru dari sumber yang tunggal maupun sumber yang beragam.Karakter yang diharapkan muncul dalam kegiatan bertanya ini adalah kemampuan untuk mengembangkan kretivitas siswa, kemampuan merumuskan pertanyaan dan rasa ingin tahu yang tinggi.

Mengumpulkan informasi, kegiatan ini dilakukan untuk menggalih dan mengumpulkan informasi dari berbagai sumber.Seharusnya peserta didik dapat membaca buku yang lebih banyak, memperhatikan fenomena atau objek yang lebih teliti atau melakukan eksperimen. Tetapi yang terjadi dilapangan menunjukkan bahwa proses pembelajaran biologi sering sekali guru mengembalikan pertanyaan tersebut kepada siswa untuk dicari tahu informasi tentang pertanyaan, namun ternyata guru juga tidak memberikan kesempatan kepada siswa untuk mengumpulkan informasi tetapi guru langsung member jawaban mengenai pertanyaan tersebut atau dengan kata lain kegiatan tahapan mengumpulkan informasi tidak terlaksana.

Mengasosiasiasikan Mengolah informasi merupakan kegiatan memproses informasi yang sudah dikumpulkan baik terbatas dari hasil kegiatan mengumpulkan maupul hasil dari kegiatan mengamati dan kegiatan mengumpulkan informasi. Pengolahan informasi yang dikumpulkan dari yang bersifat menambah keluasaan dan kedalam sampai kepada pengolahan informasi 
yang bersifat mencari solusi dari dari berbagai sumber yang memiliki pendapat yang berbeda sampai kepada yang bertentangan.Kegiatan ini dilakukan untuk menemukan keterkaitan suatu informasi dengan informasi lainnya, menemukan pola dan keterkaitan informasi tersebut.

Mengkomunikasikan, pada pendekatan saintifik guru diharapkan member kesempatan kepada peserta didik untuk untuk mengkomunikasikan apa yang telah mereka pelajari. Kegiatan ini dapat dilakukan melalui menuliskan atau menceritakan apa yang ditemukan dalam kegiatan dalam mencari informasi, mengasosiasikan dan menemulakan pola. Hasil tersebut disampaikan dikelas dan dinilai oleh guru sebagai hasil belajar peserta didik atau kelompok peserta didik.

Dari keterangan tersebut, dapat disimpulkan pelaksanaan pembelajaran dengan pendekatan saintifik belum maksimal dan perlu perbaikan. Padahal jika pelaksanaan pendekatan saintifik dilakukan dengan baik, maka hasilnya akan baik. Hal ini sesuai penelitian yang dilakukan oleh Wakhidah, dkk (2016) yang menyatakan bahwa tiap langkah dalam pendekatan saintifik mampu mengkontruksi pengetahuan peserta didik, memberi kesempatan bagi peserta didik untuk memperoleh informasi secara teks dan suara, teori pemprosesan infomasi, dan teori scaffolding.

Kegiatan akhir dalam pembelajaran tidak hanya diartikan sebagai kegiatan menutup pelajaran, tetapi juga sebagai kegiatan penilaian hasil belajar peserta didik untuk membuat kesimpulan ringkasan materi yang dipelajari, memberikan umpan balik terhadap proses dan hasil pembelajaran, memberi tugas, dan menyampaikan rencana pembelajaran yang akan disampaikan pada pertemuan selanjutnya.

Pembelajaran dalam kurikulum 2013 ini memuat gagasan pokok untuk mencapai kompotensi dasar yang berpusat pada peserta didik, menantang bagi guru dan peserta didik. Untuk memperoleh hasil proses pembelajaran yang baik dan hasil yang baik, diperlukan pengelolaan pembelajaran yang baik oleh guru. Dari perbandingan analisis data, dapat disimpulkan bahwa guru biologi masih melaksanakan pembelajaran biologi sesuai Kurikulum 2013 cukup baik dan perlu adanya perbaikan.

\section{Penilaian Pembelajaran}

Penilaian memiliki peran penting dalam menetukan kesuksesan pendidikan. Penilaian yang baik memberikan dampak pada proses pembelajaran. Ketepatan pemilihan metode penilaian akan sangat berpengaruh terhadap informasi objektif dan validitas kualitas pendidikan. Sebaliknya kesalahan dalam memilih dan menerapkan metode penilaian juga berimbas pada informasi yang tidak valid mengenai hasil belajar dan pendidikan (Sani, 2016)

penilaian hasil belajar oleh
pendidikmerupakan proses pengumpulan informasi/data tentang capaian pembelajaran peserta didik aspek sikap, aspek pengetahuan, aspek keterampilan yang dilakukan secara terencana dan sistematis, untuk memantau proses, kemajuan belajar,dan perbaikan hasil belajar melalui penugasan dan hasil belajar. Penilaian hasil belajar ini dilakukan dengan assessment authentik.

Berdasarkan penelitian yang dilakukan di SMA Negeri 3 Binjai menunjukkan bahwa penilaian pembelajaran masih cukup baik yaitu dalam hal penilaian sikap yang dilakukan menurut pandangan guru hal tersebut terlalu susah untuk mengamati siswa dengan jumlah yang tergolong banyak.

Dalam penilaian pengetahuan dan keterampilan di SMA Negeri 3 Bnjai diketahuai bahwa guru biologi disekolah tersebut melakukan penilaian dengan menggunakan test tertulis seperti ulangan harian, tugas, dan ujian tengah semester. Sedangkan dalam penilaian keterampilan, guru mengumpulkan tugas siswa berupa keterampilan menulis seperti pada pembelajaran ruang lingkup, siswa diberi tugas untuk membuat karya ilmiah sederhana, keterampilan membuat kerajinan tetapi itu semua disesuaikan pada materi yang disampaikan. Pada guru melakukan tugas fortofolio dengan cara mengumpulkan tugas-tugas dari siswa sehingga tugas tidak dibawa pulang oleh siswa. 
Numun dalam penilaian pengetahuan dan keterampilanpun guru biologi belum melakukan menilaian penuh seperti yang direncanakan dalam RPP. Hal ini dikarekan duru-guru tersebut belum terbiasa dengan lembar-lembar penilaian seperti yang terdapat dalam RPP kendala guru dalam menerapkan penilaian ini adalah rumit dan sulitnya penerapan penilaian ini ditambah lagi siswa yang akan dinilai jumlahnya tidak sedikit.

Meskipun sudah mengikuti pelatihan dari MGMP tetap saja hal ini masih dikeluhkan oleh guru.Oleh sebab itu untuk penilian aspek pengetahuan guru masih banyak melakukan penilaian tanpa berdasarkan pedoman yang dibuat di RPP. Hal ini sana dengan pemaparan direktorat jendral pendidikan dasar dan menengah (2015) memaparkan beberapa pendapat yang disampaikan sebagian besar pendiddik terkait dengan penilaian yaitu, pada penilaian pengetahuan dan keterampilan masih banyak pendidik yang belum terbiasa menggunakan beberapa tekhnik penilaian, seperti fortofolio dan proyek, guru kesulitan dalam penilaian menggunakan angkadengan skala 1-4 dan masyarakat kurang memahami makna nilai hasil belajar-contoh nilai 3,12.

Sehingga dari analisis data kuantitatif dapat disimpulkan bahwa para guru biologi di SMA Negeri 3 Binjai melaksanakan penilaian pembelajaran biologi belum sesuai dengan kurikulum 2013 sesuai dengan pedoman yang tertera pada permendikbud No. 22 tahun 2016.

\section{KESIMPULAN}

Berdasarkan hasil penelitian yang diperoleh dari hasil analisis data dan wawancara guru biologi maka dapat disimpulkan sebagai berikut: Tingkat ketercapaian perencanaan pembelajaran kurikulum 2013 dengan pendekatan saintifi kadalah $85 \%$ sehingga termasuk kedalam kategori baik, Tingkat ketercapaian pelaksanaan pembelajaran kurikulum 2013 dengan pendekatan saintifik adalah $79,30 \%$ sehingga termasuk kedalam kategori cukup baik, Tingkat ketercapaian penilaian pembelajaran kurikulum 2013 dengan pendekatan saintifik adalah $79,16 \%$ sehingga termasuk kedalam kategori cukup baik

\section{UCAPAN TERIMA KASIH}

Penulis mengucapkan terima kasih kepada guru SMA Negeri 3 Binjai khususnya Ibu V. Siregar dan Ibu L. Manullang yang telah banyak membantu dalam melaksanakan penelitian ini.

\section{DAFTAR PUSTAKA}

Budiyanto, M.A.K., Waluyo, L., dan Mokhtar, A., (2016), Implementasi Pendekatan Saintifik dalam Pembelajaran di Pendidikan Dasar di Malang, Proceeding Biology Education Conference, 1: 46-51.

Kemendikbud, (2013), Permendikbud No 65 Tahun 2013 Tentang standart proses pendidikan, Kemendikbud, Jakarta.

Kemendikbud, (2013), Permendikbud No 69 Tahun 2013 Tentang Kerangka Dasar Dan Struktur Kurikulum, Kemendikbud, Jakarta.

Kemendikbud, (2014), Modul Pelatihan Implementasi Kurikulum 2013, Badan Pengembangan Sumber Daya Manusia Pendidikan dan Kebudayaan dan Penjaminan Mutu Pendidikan, Jakarta.

Kemendikbud, (2016), Peraturan Menteri Pendidikan dan Kebudayaan Republik Indonesia Nomor 22 Tahun 2016 Tentang Standar Proses Pendidikan Dasar dan Menengah, Kemendikbud, Jakarta.

Kwartolo, Y., (2007), Mengimplementasikan KTSP Dengan Pembelajaran Partisipatif Dan Tematik Menuju Suka cita Dalam Belajar (joy in learning), jurnal pendidikan penabur9 : 66-80.

Mulyasa, (2007), Pengembangan Dan Implementasi Kurikulum 2013, Remaja Rosdakarya, Bandung.

Rahmatika, U., Amrizal, (2017), Pemetaan Pembelajaran Berbasis Scientific Approach Di Sma Negeri 1 Binjai, Jurnal Pelita Pendidika,6.(1), 028-035.

Sani, R.A., (2016), Penilaian Autentik, Bumi Aksara, Jakarta.

Sanjaya, W, (2009), Pembelajaran Dalam Impelementasi Kurikulum Berbasis Kompetensi, Prenada Media, Jakarta.

Suharno, (2014), Implementasi Pembelajaran Berbasis Kurikulum 2013 Pada Mata PelajaranBiologi Di SmaNegeri 1 
JURNAL PELITA PENDIDIKAN VOL. 6 NO. 4

pISSN : $2338-3003$

Siregar, M.K., \& Amrizal

eISSN : $2502-3217$

Halaman : 238- 246

Gondang Kabupaten Tulungagung, Jurnal Humanity, 10(1) : 147-157.

Wakhidah, (2016) pendekatan saintifik dalam pembelajaran ditinjau dari berbagai perspektif teori belajar, prosiding seminar nasional.

Widjaja, (2010), Komunikasi dan Hubungan Masyarakat, BumiAksara, Jakarta. 